\title{
MAKING A LIVING ON CORAL ATOLL: CHANGING STRATEGIES AMONG MILLENNIALS ON BALOBALOANG ISLAND, SOUTH SULAWESI, INDONESIA
}

\author{
Gene Ammarell ${ }^{1}$, Muslimin ${ }^{2}$, Sukur Oda ${ }^{3}$, Ahmad Faisal $\mathbf{R}^{4}$ \\ ${ }^{1}$ Associate Professor Emeritus of Anthropology, Ohio University, and Adjunct Professor of \\ Anthropology, Hasanuddin University \\ ${ }^{2}$ Regional Planning and Development, Graduate School, Hasanuddin University, Makassar \\ ${ }^{3}$ Regional Planning and Development, Graduate School, Hasanuddin University, Makassar \\ ${ }^{4}$ Marine Science and Fisheries, Graduate School, Bogor Agriculture Institute, Bogor. \\ *Corresponding author: ammarell@ohio.edu
}

Citation: Ammarell, G., Muslimin., Oda, S., Faisal, A. 2021. Making A Living On Coral Atoll: Changing Strategies Among Millennials On Balobaloang Island, South Sulawesi, Indonesia. J. Asian Rur. Stud. 5(1): 1-29

\begin{abstract}
Beginning around 2014, some significant changes in the livelihoods among many younger men from the Island of Balobaloang, South Sulawesi, Indonesia, emerged. This study describes and explains how it is that approximately 50 working-age adult men (out of a total population of about 900) have turned away from interisland shipping and trade and artisanal fishing and toward wage employment aboard tourist ships, working out of distant ports in Indonesia. This case study uses a qualitative approach to explore and describe the socioeconomic life of community members on the island village of Greater Balobaloang as they continue to be affected by economic and environmental changes. Field data collection was carried out through observation, government documents, and in-depth interviews with respondents. In particular, this study focuses on the adaptive strategies of younger men as opportunities for making a living have shifted in recent years away from artisanal fishing and interisland shipping and trade to adventure travel aboard modified traditional sailing ships. It contributes to discussions of internal skilled migration, social mobility and adaptation to the domestic and international tourist industry.
\end{abstract}

Keywords: Social Economic Change; Migration; Tourism; Fishing; Shipping and Trade

\section{Introduction}

For some decades now, South-East Asia has been characterized by rapid economic and socio-cultural transformations involving large movements of people and goods within and between countries as well as rural and urban areas. In addition to classical spatial mobility patterns of rural-urban migration, international labor migration, and international tourism becoming increasingly dynamic, forms of multi-local household arrangements, skilled migration, transnational communities or long-term tourism and domestic tourism have emerged. In this context, one can observe a number of interdependent forms of mobility, including the physical movement of people for reasons of work, leisure, family, or lifestyle as 
well as the physical movement of objects from and to producers, consumers, retailers, and

the different places where people live, work, or go on holidays. Trupp, A., \& Dolezal, C.

(2013: 235)

With limited access to governmental and commercial services, poor communication and information technology facilities, and less than optimal educational facilities, the people of Balobaloang Island, a small coral islet located in Indonesia's Flores Sea, continue, as they have in the past, to seek out and create alternatives, that is, adapt to the conditions in which they find themselves. Given these factors, villagers are currently adapting to two serious economic challenges: increased competition in interisland shipping and trade and depleted marine resources, the latter due to anthropogenic damage sustained by the surrounding reef that has occurred over the past three decades. Taken together, these are serious concerns that serve to threaten the sustainability of people's lives and livelihoods on the island.

Beginning around 2014, some significant changes emerged in the livelihoods among many younger men from the Island of Balobaloang. This study describes and explains how it is that approximately 50 working-age adult men (out of a total population of about 900) have turned away from interisland shipping and trade and artisanal fishing and toward wage employment aboard tourist ships, working out of distant ports in Indonesia. This case study uses a qualitative approach to explore and describe the socio-economic life of community members on the island village of Greater Balobaloang as they continue to be affected by economic and environmental changes. Field data collection was carried out through observation, government documents, and in-depth interviews with respondents. In particular, this study focuses on the adaptive strategies of younger men as opportunities for making a living have shifted in recent years away from artisanal fishing and interisland shipping and trade to adventure travel aboard modified traditional sailing ships.

\subsection{Marine Biodiversity Under Threat}

All human communities face social, political, economic, and environmental challenges that are both general to all and specific to each (Kusnadi, 2009; Satria, A., Anggraini, E., and Solihin, A., 2009). One such challenge is that of marine resource degradation for coastal and small island communities (Kusnadi, 2009). While the World Resources Institute (2002) rated Indonesia as having the most abundant marine biodiversity in the world, much of this biodiversity is under threat. For example, between 1980 and 2005, 120,000 hectares (ha) of mangrove forest, one of the essential components in coastal ecosystems, was converted to agricultural land (KLH, 2009). In addition, monitoring of coral reef conditions by Coremap II and P2PI LIPI in 985 locations across Indonesia in 2008, showed that only 5.51 percent of the 
samples were in excellent condition, 25.48 percent were in good condition, 37.06 percent were in insufficient condition, and 31.98 percent were in damaged condition (Giyanto, 2017).

Dahuri, among others, emphasizes that while human needs are increasing, the carrying capacity of the earth's natural resources is limited, inevitably accelerating anthropogenic damage to natural resources upon which human beings depend (Dahuri, et al., 1996). This certainly is the case for many subsistence and small-scale commercial fishers and their communities (Satria, 2009). Thus, the rapid depletion of populations of fish and other marine resources has led to the emergence of various responses by members of maritime communities in the form of both the conservation and rehabilitation of habitats as well as adaptive adjustments in the seeking of livelihoods.

\subsection{The Study of Adaptation and Change in a Small Maritime Community}

Adaptation is a system of ongoing interactions between all members of ecosystems, for example, between humans and humans and between humans and other members of ecosystems. Thus, human activities change environments while environments condition human activities. For example, while human activities contribute to climate change, a changing climate requires adaptations so that humans can survive and sustain life within a changing environment (Bennett 2017).

Change is an inevitable part of all existence. As bio-cultural organisms, human beings respond to change both genetically and epigenetically through natural selection and socially through choices and actions, both conscious and unconscious. Of course, many of these responses are not successful, or "non-adaptive" and, thus, do not survive or carry forward. Likewise, human adaptations can result in things expected or unexpected, with unintended consequences that may be found to be detrimental or no adaptive. Whether successful or not, these responses are, themselves, instigators of change in an endless and complex process of cause and effect. Bennet (1976) and Pandey (1993) discuss adaptation as a human response to environmental change. They premise their work on the notion that humans have the ability to develop and organize individual and collective behavioral responses to change in their environments so that they can adapt to new situations and conditions. Such behavior is related to life needs and wants, wherein individuals, drawing upon previous experiences, make decisions and create strategies to deal with subsequent events.

Thus, adaptation is a strategy used by humans to anticipate and/or respond to environmental changes both physically and socially (Alland, 1975; Barlett, 1980). Just as there are many causes and conditions that result in adaptations in procuring livelihoods, adaptive responses across time and space are innumerable, including those which are carried out in situ, 
i.e., finding new sources of livelihood while remaining in one's home village or town, and those which rely on mobility and migration to procure one's livelihood in distant locations. In the latter case, this might include regular, often seasonal, travel outside of one's place of residence and return, or it may include semi-permanent or permanent change of residence, often with remittances sent home to family members.

Multiple studies discuss how coastal communities have adapted to environmental changes over time. For example, Helmi and Satria (2012) examined the adaptive strategies of fishermen to ecological changes in the coastal village of Pulau Panjang in South Kalimantan, Indonesia. Human exploitation of coastal resources led to the destruction of mangroves and coral reefs. Adaptation strategies applied by fishers and their households were found to have varied and included diversification of sources of income, reliance on social relations, mobilization of household members, expansion of types of fishing gear, exploitation of additional fishing areas and logging illegal mangrove forest.

Another adaptation that is common among coastal and other rural communities is the welcoming of tourists and the development of a tourist industry, with studies focusing on the economic, social, and environmental impacts of tourism on the local populations. For example, Picard (2007) describes the ambivalent relationship between local Malagasy, international tourists, and other social actors as the Malagasy seek solutions to the destruction of their fishery from coral bleaching. Closer to home, on the island of Bali, one of the destinations for some of the tourists who travel aboard ships crewed by seafarers from Balobaloang, Dolezal (2013) disambiguates the extent to which tourism has become a source of economic and social empowerment for members of a tourist community. The present study contributes to the literature on local adaptations to environmental and economic changes in coastal and island communities, describing an instance, perhaps unique in the literature, in which a large segment of a village's male population both continues and transforms their historic maritime traditions as they migrate to fill the specialized needs of a particular type of tourism, i.e., adventure travel aboard modified traditional trading ships for diving and relaxation.

This study follows upon three decades of research on the small coral islet of Greater Balobaloang, one of over thirty islands in Indonesia's Sabalana Archipelago and is located 112 nautical miles south-southeast of the provincial capital of Makassar (Ammarell 1999, 2009, 2011, 2014, 2016; Hapsari and Ammarell 2008; Hlavacs 2008; Stein 2005). Ammarell's initial studies focused on expert navigational knowledge and practices among captains and crews of local interisland trading ships at a time when work aboard these ships was the major source of income for villagers and fishing was carried out primarily for subsistence. While there had been occasional instances of blast fishing carried out in the Sabalana's in prior decades for 
subsistence and ritual purposes, commercial blast and cyanide fishing by fishers from other islands took hold and accelerated rapidly beginning in the early 1990s. Beginning in 2003, research was focused on the physical and biological impacts of destructive fishing and the condition of the surround reef (Hlavacs, 2008; Stein, 2005) and upon the social and economic impacts and adaptations by local fishers with the decline in the fishery and the added physical, economic, and social costs of commercial and subsistence artisanal fishing (Ammarell, 2011, 2014; Hapsari and Ammarell, 2008).

The present study takes a close look at some significant changes in the livelihoods among many younger men from the island beginning around 2014. Specifically, it seeks to describe and explain how it is that approximately 50 working-age adult men (out of a total population of about 900) have turned away from interisland shipping and trade and artisanal fishing and toward wage employment aboard tourist ships, working out of distant ports in Indonesia.

\section{Research Methods}

This case study uses a qualitative approach to explore and describe the socio-economic life of community members on the island village of Greater Balobaloang as they continue to be affected by economic and environmental changes. Field data collection was carried out through observation, government documents, and in-depth interviews with respondents. In particular, this study focuses on the adaptive strategies of younger men as opportunities for making a living have shifted in recent years away from artisanal fishing and interisland shipping and trade.

The research was conducted on 8-13 April 2019 on Greater Balobaloang Island, one of five islands comprising the Village of Balobaloang and one of over thirty islands which make up the District of Liukang Tangaya, the remotest islands in the Regency of Pangkajene and Kepulauan,

The population interviewed for this study were residents of Greater Balobaloang at the time of the research. Given Ammarell's familiarity with the village and its residents as well as the short time of this study, in-depth interviews began with Ammarell's primary contacts, including ship owners, fishermen, and local government officials. These interviews were followed by snowball sampling of men and their families who had or were currently working aboard local cargo ships, as fishermen, or aboard tourist ships in eastern Indonesia. Of the men who were working on tourist ships, we were able to interview only those who were either home on leave or whose employment had been terminated.

The data collected in this study includes two types. Primary data was obtained through direct observations, semi-structured interviews (many recorded), and photographs at the site and 
aboard ship travelling to and from the site. Secondary data was obtained from the village administration such as population, area, boundaries, number of heads of households, and other village administrative records. Previously published and unpublished ethnographic studies of the peoples of Balobaloang as well as studies of the condition of surrounding reef were also relied upon. Each evening, the research team met to present and discuss the day's findings. Based upon these discussions, new questions arose that became the prompts for the following day's work. Thus, emerged topics that were deemed relevant to this study. Having returned from the field, further analysis of the data alerted the authors to gaps that were filled by contacting villagers, both in person on the mainland and by phone and text messaging to the island.

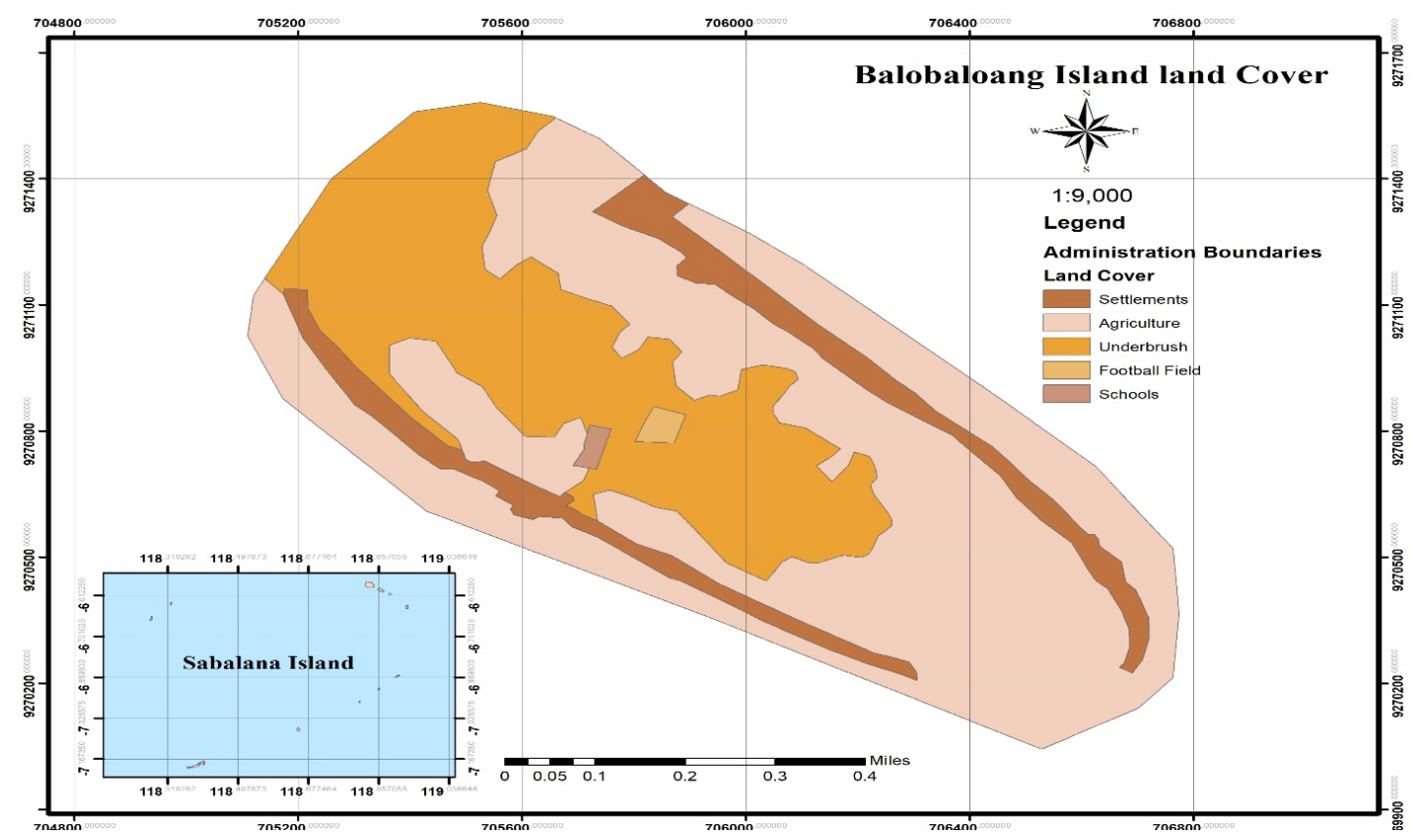

Map 1: Land Cover Map of Balobaloang Island 


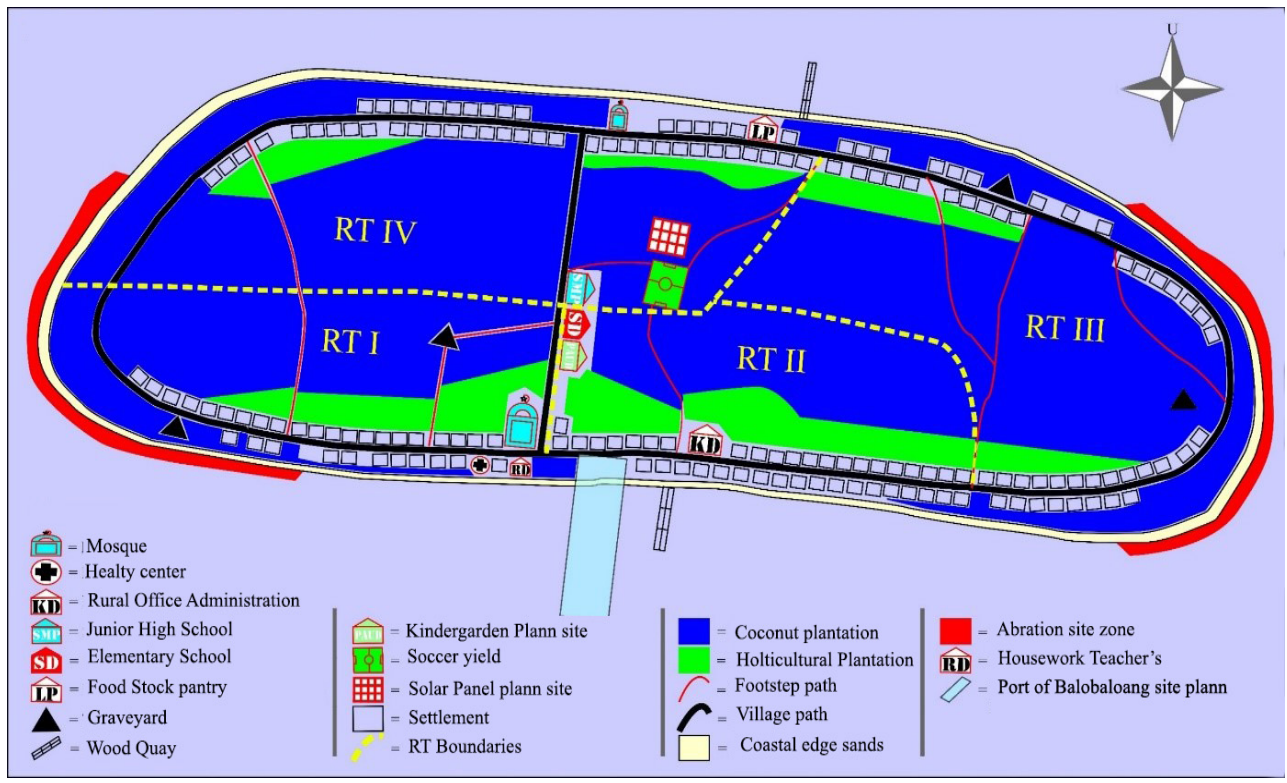

Map 2: Political Map of Balobaloang Island

\section{Research Findings and Discussion}

\subsection{Coastal and Island Societies; Greater Balobaloang}

Members of maritime coastal communities settle and live along the coastlines of continents and of large and small islands. Historically they have secured livelihoods as fishers, shipbuilders, fish processors, laborers and merchants; more recently some have joined the sector that provides services to tourists. As discussed above, human beings adapt to the local environment which they inhabit. Thus, coastal communities have carved out livelihoods that rely at least in part on marine resources but not without variation over time and space. For example, people who live in port cities whose ancestors may have relied on shipping and trade and artisanal fishing for subsistence and as a source of income, today may find employment laboring in seaports, shipbuilding, crewing aboard ships, or in the processing, resale, or export of fish, while others may work in the food service industry, serving seafood to tourists and local residents.

On the other hand, although there are different priorities across small coastal and island communities, among the constellation of coastal populations marine resources are the principle means by which individuals secure their livelihoods. Thus, if these resources are degraded, it threatens the integrity and sustainability of the lives of coastal communities, especially those who live on small islands. Sutardjo in Firdaus et al., (2016) suggests that there are four main challenges faced by coastal communities, namely, poverty, and damage to aquatic resources, 
lack of autonomy of local community organizations, and infrastructure and environmental health. Moreover, coastal areas of small islands are often located far from access to information, technology, and infrastructure development - all priorities in supporting the welfare of the community - while governments cannot keep up with the need for additional infrastructure and improved education opportunities. For many, these challenges have resulted in increased poverty, poorer health, and out-migration to cities, while for others, new opportunities arise and are seized upon that improve their economic lives. In all of these dimensions, Balobaloang may be seen as emblematic.

Not unlike members of coastal communities world-wide, whether large or small, residents of Balobaloang are facing increasing challenges due to population growth, increasing demand for limited resources, and the environmental impacts of climate change, pollution, overfishing, and destructive fishing practices. For Balobaloang, as with the other islands of the Sabalana Archipelago, the distance from the capital city of the regency creates many obstacles to economic development, while limited access to information and communication technologies makes it quite difficult for villagers to communicate with the rest of the regency. Urban centers, as the foci of development and where major access to support and infrastructure in a region resides, play a critical role in developing the region in the creation and promotion of the welfare of its population. However, from a geographical point of view, the remoteness of Balobaloang Island from the metropole makes it difficult to access its resources such that the community must develop strategies to support and maintain the sustainability of life and livelihood on this small island. With limited access to governmental and commercial services, poor communication and information technology facilities, and less than optimal educational facilities, the people of Balobaloang Island continue, as they have in the past, to seek out and create alternatives, that is, adapt to the conditions in which they find themselves. Given these factors, villagers are currently adapting to two serious economic challenges: increased competition in interisland shipping and trade and depleted marine resources, the latter due to anthropogenic damage sustained by the surrounding reef that has occurred over the past three decades. Taken together, these are serious concerns that serve to threaten the sustainability of people's lives and livelihoods on the island.

\subsection{Procuring Livelihoods: Income Security and Job Diversity}

While marine resources play a significant role in the constellation of possible livelihoods of coastal and island communities, most members of these communities are not engaged in a single vocation. That is, for the majority of residents, the gathering, processing, and marketing fish and other resources from the sea, are not the dominant source of income. Historically, and 
up through the present, individuals have engaged in multiple occupations with various degrees of expertise in order to maximize income security and even provide extra income that could be used for education and capital expenditures. The primary examples of this can be seen in families that gain income from one or more traditional occupations, including carpentry (homes and boats), coconut cultivation and processing, artisanal fishing, and interisland shipping and trade.

From the settlement of the island of Balobaloang in the late $19^{\text {th }}$ century, residents have cultivated bananas and coconuts, providing both subsistence and income, with surplus coconuts sold fresh in port and processed into copra for the international market. In fact, in Bugis culture, coconuts have long been seen as an economic "safety net," such that coconut trees have been a required part of the bride wealth offered by the groom's family during marriage negotiations. Today, copra is still made from local coconuts while the shells are turned into charcoal, both of which are shipped to, and sold in Makassar (Ammarell, 1999). In earlier times, many of the families of Balobaloang built and owned 5-15 ton sailing ships, used for transporting people and cargos between the islands and the mainland ports and for fishing wherein the owner/captain and small crew would fish for days and weeks at a time, salt and dry the fish, and sell them in port. Fish for subsistence was more often caught from dugouts close to the island, although surpluses were dried and sold in port (Ammarell, 1999).

Over time, families built larger and larger ships and increasingly engaged in interisland trade and, later, consigned shipping between ports in Sulawesi, Kalimantan, Java and islands in eastern Indonesia. During the 1980s, ship owners began to install auxiliary diesel engines, and by 1990 , it was virtually impossible to get a valuable cargo on consignment without such an engine. During this period, crew members would often move back and forth between cargo ships and fishing, depending upon the season and potential profits. By then, the ships of Balobaloang, numbering more than 20, cornered a big part of the trade between Makassar and Bima and other ports. At its peak in the early $21^{\text {st }}$ century, there were as many as 40 cargo ships owned and operated by residents of Balobaloang and nearby islands. However, as competition for cargos has grown and profits have declined in recent years, the number of ships has dwindled to about 10, with owners and crew members having to find new livelihoods in order to support themselves and their families (Ammarell, 1999).

Thus, when winds increase, typically during the monsoons, fishing becomes difficult or impossible, and many fishermen would go to sea aboard local trading ships to seek more secure income. This was especially so in the past before motorization when cargo ships were powered by sail and relied upon the wind while fishing was primarily from sailing dugouts, or lépa-lépa, that were best adapted to calm and gentle winds that occur between the monsoons. With the 
onset of the east monsoon, coconuts were harvested from trees owned by many families and both copra and fresh coconuts were loaded aboard ships to be sold in port as an initial cargo. Prior to motorization, ships and their crews were often gone for several months until the end of the east monsoon and the onset of a period of calm winds before the onset of the west monsoon. Even with motorization, ships and their crews might be absent from the village for several months at a time, earning as much money as possible as long as favorable conditions existed (Ammarell, 1999).

At times when fishing was most profitable (i.e., during months of calm winds and seas between the monsoons, when the price of fish was favorable, and, in the past, when fish were abundant and easily harvested near to the island), many men from across families would return to the island and take up fishing. Meanwhile, several fulltime fishermen persisted, even in hard times, due to their strong preferences for the independence of owning and operating one's own boat and the ability to stay close to home and one's family, this, in spite of the relative difficulty of spending long days under a tropical sun with no guarantee of a good catch.

Beginning around 1990, small-scale commercial fishers from other islands began to use destructive fishing methods - explosives and cyanide provided by "bosses" - to capture fish for the regional and international markets. These practices, generally anathema to the fishers of Balobaloang, made it impossible to subsist, let alone gain income, from fishing in dugouts near to the island where the reef suffered near total destruction. Thus, fishers turned to small plank boats with diesel engines to fish further and further across the reef, resulting in somewhat better catches but with increased costs; at one point, only a handful of men sought their livelihood from fishing. During the last decade, however, fishing has become more profitable for those who will spend days at sea far from home. The introduction of ice boats has allowed fishers to have their catches transported and sold as "fresh" in Makassar while GPS and fish finders have enabled them to locate larger fish at depths unreachable by the destructive fishers.

There are, of course, many variations on this scenario, with some ship owners having to turn to fishing fulltime when they could no longer afford the expense of maintaining their ships, while some men and their sons have spent most of their lives relying almost entirely on fishing or interisland shipping and trade. In addition, whether fisher or crew member, most men have worked as carpenters, building and repairing their fishing boats and/or the superstructures of the cargo ships they own or upon which they crew.

Most recently, and the subject of this article, is the opening of a new vocation for many of the younger men of Balobaloang. Drawing upon traditional skills aboard cargo ships, many men have found positions aboard tourist ships operating in eastern Indonesia. The lure of greater incomes and easier working conditions have enticed these men, even though it means 
being away from home for up to 11 months each year. With extended families back in the village to look after one another, as in the past, absence remains a price to pay for added economic security. The tables below summarize the estimated average current incomes from commercial artisanal fishing as well as work as crew members aboard cargo and tourist ships by the members of the Balobaloang community during the month of April 2019. Note that due to favorable weather conditions, April is usually a particularly profitable month for both fishing and carrying cargo in this region.

Table 1. Incomes from Fishing

\begin{tabular}{|c|c|c|c|}
\hline & $\begin{array}{c}\text { Fish Iced and Sold as } \\
\text { Fresh }\end{array}$ & $\begin{array}{c}\text { Fish Dried and } \\
\text { Salted }\end{array}$ & Notes \\
\hline $\begin{array}{c}\text { Price paid per } \\
\text { kilogram (April } \\
\text { 2019) }\end{array}$ & $*$ USD $1.40 / \mathrm{kg}$ & *USD 3.15/kg & \multirow{3}{*}{$\begin{array}{l}\text { * The price of gasoline or } \\
\text { diesel and the cost of } \\
\text { maintenance of the boat and } \\
\text { ship's engine have not been } \\
\text { deducted. }\end{array}$} \\
\hline $\begin{array}{l}\text { Average minimum } \\
\text { catch }\end{array}$ & $100 \mathrm{~kg}$ & $100 / \mathrm{kg}$ & \\
\hline $\begin{array}{l}\text { Average maximum } \\
\text { catch }\end{array}$ & $200 \mathrm{~kg}$ & $200 \mathrm{~kg}$ & \\
\hline
\end{tabular}

Range of gross monthly incomes from artisanal commercial fishing during April 2019, can be seen in the above Table. This includes only those residents who rely primarily on fishing for their incomes. (Albar, personal communication).

Table 2. Incomes from Working as Crew Members Aboard Cargo Ships

\begin{tabular}{ccc}
\hline Position & Share(s) of profits & Profit from one month's voyaging $\sim$ USD 2100 \\
\hline Captain & 3 & USD 210./trip \\
\hline Engineer & 2 & USD 140/trip \\
\hline Other crew member & 1 & USD 70/trip \\
\hline
\end{tabular}

Incomes are based upon traditional "share" method of distributing profits aboard a Bugis cargo ship (Tobing 1961, Ammarell 1999). Details of profit sharing with a gross income of USD 2100 aboard the cargo ship KM Farida Setia, capacity 200 ton, engine GT 100, and with a team of eight people. Owner: Albar. (Albar, personal communication) 
Table 3. Incomes from Working Aboard Tourist Ships

\begin{tabular}{llll}
\hline \multicolumn{1}{c}{ Position } & \multicolumn{1}{c}{ Salary } & $\begin{array}{c}\text { Accommodations/ } \\
\text { Living Expenses }\end{array}$ & \multicolumn{1}{c}{ Tips } \\
\hline $\begin{array}{l}\text { Captain } \\
\text { Engineer }\end{array}$ & USD 350/month & & \\
Other crew member & USD 280/month & USD 35/person/trip & $\begin{array}{l}\text { USD 70- } \\
140 / \text { person/trip }\end{array}$ \\
\hline
\end{tabular}

Average incomes from wages, expenses, and tips earned by crew members aboard the privatelyowned tourist ship Epica (Scuba Republic Corp.) in April 2019. (Iwan, personal communication)

\subsection{Social and environmental changes over the lifetimes of millennial}

Over the past three decades, much has changed for the people of Balobaloang, bringing both new opportunities and new challenges. Here we summarize several of the changes that have emerged in recent years that have directly or indirectly influenced the choices young men have made in pursuit of livelihoods that promote the economic and social well-being of themselves and their families. These include improved access to education and healthcare, gains and losses in village infrastructure, introduction, albeit relatively slow, of new communication technologies, and environmental degradation.

\subsubsection{Education}

Education plays a critical role in the development of individuals and societies, enabling individuals and communities to better adapt to changing economic, technological, environmental and social conditions, to improve the management of its resources, and to improve the quality of participation in community governance. As of 1991, there were no resident full-time teachers, and the one useable school building was in a state of disrepair. Often, there were no teachers present as children came and went from the school at will or simply playing in the schoolyard.

Several of the wealthier families sent one of their children to school in Makassar or Pangkep, with only a handful completing secondary education. In stark contrast, access to a good education on Balobaloang has grown over the last three decades, but it is still limited to elementary and junior high school. To attend high school, students have to go to public or private schools in the cities of Makassar or Pangkep, a costly but increasingly common option. For those who do attain higher levels of education, new and more lucrative forms of 
employment have, in fact, become available, including work aboard tourist ships. Table 4 provides a sample of the current educational attainments of young people from Balobaloang.

Table 4: Educational Facilities and Student Attainments

\begin{tabular}{ccc}
\hline Levels & Year Opened & Completed level in 2019 \\
\hline Kindergarten/ Preschool & 2016 & 43 \\
\hline Elementary & 1994 & 89 \\
\hline Junior High & 2006 & 57 \\
\hline Senior High & - & 78 \\
\hline Graduate Diploma & - & 11
\end{tabular}

*Senior high school and college attended in Pangkep and Makassar City.

\subsubsection{Healthcare and Wellness}

Whereas in 1991, Balobaloang had only a part time and poorly trained health worker, as of 2019, it has a government facility (Pustu) with two trained health workers. For prenatal care and birthing, there are two additional women who work as midwives but are not attached to the facility, so when a woman is pregnant, she has the assistance of up to four health workers. The main government clinic (Puskesmas), itself, is located on Sapuka Island, the district center, about 58 miles (about five hours by fishing boat) away, so when in need of more serious treatment, community members often prefer to travel the 110 miles by ship or ferry boat to Makassar where they can access more complete facilities.

\subsubsection{Infrastructure}

Balobaloang's infrastructure has improved in recent years through external government funding and local taxation procured by local officials. However, there are still many facilities that are lacking or in need of repair. Electrification of the island is currently incomplete. Two decades ago, a village generator and transmission lines were installed, reaching almost every home on the island. Eventually, that generator broke down and was replaced, but that one, too, broke down, and much of the grid has fallen into disrepair. At present, some people use personal generators and/or solar panels as an alternative lighting solution. With a wattage capacity that is not too large, each house has at least one solar panel. Some stretches of the road network are also equipped with solar panels to power street lighting at night.

A pier that once stood on the south (reef) side of the island near to the most densely populated part of the island has collapsed due to poor maintenance. The absence of the pier makes it much more difficult to take on and discharge passengers and cargo at that location. Because it is now impossible for cargo ships and ferry boats to dock, they must anchor beyond 
the edge of the reef flat, often damaging coral with their anchors and leading to great inefficiencies. While a new pier was built recently on the north side of the island, the majority of goods and passengers must travel nearly a mile by footpath and narrow roadway to access it. The road network, itself, is constructed of paving block and is almost complete; only 100 meters of the path on the east end of the island is still unpaved. Paving blocks now cover most of what were the main footpaths around and across the island, while, as mentioned above, at a few locations streetlights that rely on solar panels have been installed

Perhaps the weakest link in Balobaloang's infrastructure is in the arena of information and technology networks. Cellular telephone signals are still minimal, hampering access to information, both personal and commercial on this island. While Balobaloang still lacks a cell phone tower, a weak signal can be picked up under limited atmospheric conditions from another island such that opportunities for texting and even conversations by cell phone are available for a brief period of time almost every day. To do so, residents hang their cellphones in small make-shift booths on posts near water's edge where they can make calls or send and receive text messages to friends and relatives or for business purposes off island. However, as the cell phone alert is not too loud, the owner won't know that there is an incoming call unless they are waiting nearby or unless someone else hears it and runs to let the owner know. Moreover, the power of smartphones is not strong enough to pick up the weak signal, so only simple Nokia phones can be used.

Motorization and the use of GPS aboard ships and fishing boats has made it possible to travel to distant ports and fishing grounds more easily and safely in a fraction of the time that was formerly possible with small dugouts under sail and paddle. After the turn of the millennium, as has been described, there was a devastating downturn in the local fishing industry due to the destruction of much of the fishery through the practices of blast and cyanide fishing by outsiders. With the recent introduction of ice boats owned and operated by fellow villagers and the acquisition of GPS and fish finders, the profitability of artisanal commercial fishing has increased significantly, making it possible for those fishermen who are willing to travel further and live aboard their small vessels for a week or more per trip to realize a profit once again. Radio communication and the use of satellite phones has become more commonplace among ship owners, enabling them to communicate with their ships in distant ports, while families can stay in touch more easily.

In addition, the use of generators and televisions with satellite dishes provides villagers an access to news and entertainment, radically increasing people's exposure to urban, national, and international affairs and the consumer economy. Thus, even while modernization and improvements in the quality of life continues on Balobaloang, shifts in the economy have both 
limited older occupations and opened up new job opportunities for a younger generation who are both familiar with life aboard ships and are worldlier and better educated than their forbearers, preferring to earn a better living with less drudgery.

\subsubsection{Environmental Degradation}

Three major forms of environmental degradation threaten the island's inhabitants: the destruction of the local fishery, rising sea levels, and dwindling supplies of potable water. In the face of each, villagers are working to adapt for themselves and for future generations. The destruction of the fishery through blast fishing and cyanide poisoning is discussed further on in this article (Appendix), and elsewhere (Ammarell 2016, Chozin 2008). Suffice to say here, it continues to be an intractable problem and, without the intervention of outside authorities, villagers bemoan the fact that it will only get worse.

To obtain fresh water, the community has always relied on wells dug to the depth of the freshwater lens, usually three or four meters below the surface of the ground. While potable water was generally available year-round up until a decade ago, now the fresh water is used up by the end of the dry season, and only brackish water remains in the wells until the rains return. Thus, during the period of September to December, the community must transport water from other islands which still have a surplus of fresh water, incurring time, labor, and transportation costs. It is not clear why Balobaloang's fresh water lens has become so depleted in recent years, but it is likely some combination of increased demand from a growing population, decreased precipitation and/or increased incursion of sea water during storm surges due to climate change, and changing horticultural practices, particularly the cutting down of breadfruit trees that are said to help conserve fresh water.

Table 5. Population changes on Balobaloang Island

\begin{tabular}{lllll}
\hline Year of Census & 1970 & 1980 & 1990 & 2017 \\
\hline Population & 588 & 574 & 701 & 917 \\
\hline
\end{tabular}

Regarding rising sea levels, it is difficult without further research to discern a causal relationship, but since it was first inhabited in the late 19th century, parts of the coast have continually subsided while other parts have built up. This is normal for coral islets, but in the last few decades, the rate of erosion seems to have increased as larger and more frequent storm surges occur. Thus, the southwestern end of the island, once the site of a lucrative coconut palm grove built up over decades, has experienced severe erosion such that large numbers of trees have fallen into the ocean and the path to that end of the island has all but disappeared. Meanwhile, in the past ten years, storm surges have washed out land on the south and southeast 
coasts of the island, cutting into family coconut groves and contaminating the ground and possibly the aquifer with salt.

\subsection{Responding to Change: Community Strategies and Shifting Livelihoods}

Beginning in 2014, a significant shift in livelihoods took root on Balobaloang with younger men starting to move from fishing and interisland shipping and trade to working aboard tourist ships. Leading up to and setting the stage for this change, in 2012, the owner of the Mega Buana, Saharula, was approached by a French tourist company who wanted to contract his ship and crew for the peak tourist months of May, June, July, and August to temporarily retrofit the ship to meet minimum standards for accommodation and carry scuba divers and other tourists around Bali. From its launch in 2004, the Mega Buana had served as a cargo ship from Balobaloang, typically traveling between ports at Bima, Makassar, and Jeneponto. With eight crew members from Balobaloang, it transported fish, coconuts, ice, onions, farm animals (buffalo, horse) and other cargos, and it continued to do so throughout the rest of the year when not under contract for tourism. As more and more tourists were attracted to these traditional local ships, the contract was extended to include additional months each year until, in 2017 it went to a year round contract. Soon, a second cargo ship from Balobaloang, the Makmur Ilahi, was purchased outright and was converted by its German owner into a luxury charter ship captained and crewed by men from Balobaloang (Alexa Private Cruises webpage, Retrieved June 30, 2020).

Meanwhile, as demand grew among tourists for diving and other maritime adventures, tour operators responded by converting local ships and hiring skilled crew members to work as captains, mechanics, and crew. Word quickly spread among young men on Balobaloang who had the required skills and were willing to acquire the required government certification to work aboard the ships. Soon, approximately fifty young men from Balobaloang became employed in the tourist industry in Labuan Bajo, Papua, and Bali. They found work on tourist boats as captains, engineers, and crew members. In addition to better working conditions and larger, more reliable salaries, the teams of men from Balobaloang are gaining new skills in service management, foreign language acquisition, and hospitality while they are living a more comfortable and worldly life than they would if they were working as fishermen or crew on cargo ships.

From their increased incomes, they see an improvement in their standards of living. They send money to families on the island, which can be used to build new homes or pay the costs of education for family members. Thus, as fishing has become more difficult work and as the number of cargo ships has decreased, requiring fewer crew members, the number of men 
employed in tourism has grown. Self-reported advantages and disadvantages of the three occupations can be seen in the table below.

Table 5. Advantages and disadvantages of available occupations

\begin{tabular}{|c|c|c|}
\hline Occupation & Advantages & Disadvantages \\
\hline $\begin{array}{l}\text { Crew aboard cargo } \\
\text { ships }\end{array}$ & $\begin{array}{l}\text { - Personalistic: working with } \\
\text { other villagers } \\
\text { - Some earn enough to build } \\
\text { their own ships } \\
\text { - Large income at irregular } \\
\text { times } \\
\text { - Can work as crew without } \\
\text { certifications }\end{array}$ & $\begin{array}{l}\text { - Irregular absence from home } \\
\text { - Risk of a serious accidents } \\
\text { - Relatively low, variable income for crew } \\
\text { - Loading and unloading cargoes }\end{array}$ \\
\hline $\begin{array}{l}\text { Artisanal } \\
\text { commercial fishing }\end{array}$ & $\begin{array}{l}\text { - Modern fishing gear } \\
\text { subsidized by government } \\
\text { - High profits when fish are } \\
\text { abundant } \\
\text { - Independent entrepreneur }\end{array}$ & $\begin{array}{l}\text { - Nearby fishery depleted; must travel far to } \\
\text { fishing grounds ( } \sim 20 \text { miles }) \\
\text { - Cost of fuel, boat maintenance } \\
\text { - Harsh life aboard small boat } \\
\text { - Risk of serious accidents }\end{array}$ \\
\hline $\begin{array}{l}\text { Crew aboard a } \\
\text { tourist ship }\end{array}$ & $\begin{array}{l}\text { - Higher, regular income } \\
\text { - Gain discipline } \\
\text { - Low risk of accidents } \\
\text { - Knowledge increases } \\
\text { - Regular work schedule }\end{array}$ & $\begin{array}{l}\text { - Difficult to master foreign languages } \\
\text { - Not used to required discipline } \\
\text { - Far from home and long absences (11 } \\
\text { months per year) }\end{array}$ \\
\hline
\end{tabular}

Table 6: Tourist Ships Crewed by Men from Balobaloang

\begin{tabular}{lllll}
\hline NO. & \multicolumn{1}{c}{ BOAT } & \multicolumn{1}{c}{ POSITION } & CREW & \multicolumn{1}{c}{ ROUTES } \\
\hline 1 & ALEXA & Captain, Crew & 5 & Komodo-Raja Ampat \\
\hline 2 & EPICA & $\begin{array}{l}\text { Captain, Engineer, } \\
\text { Crew }\end{array}$ & 6 & Raja Ampat-Komodo-South Sulawesi \\
\hline 3 & SIPULIANG PINISI & Captain, Engineer & 6 & Labuan Bajo \\
\hline 4 & GURSCUBA & Captain, Crew & 6 & - \\
\hline 5 & CAJOMA III PINISI & Engineers, Crew & 6 & Labuan Bajo-Flores \\
\hline 7 & OCEANUS PINISI & Captain, Engineer & 5 & Komodo-Labuan Bajo-Flores \\
\hline 8 & BUSY GIRL & Captain, Engineer & 2 & - \\
\hline 9 & FREDERICK & Captain, Engineer & 5 & Komodo-Labuan Bajo-Flores \\
\hline 10 & KOMODO & Captain, Engineer & 6 & Komodo-Labuan Bajo-Flores \\
\hline 11 & HIU BODOH & Engineers, Crew & 6 & Komodo-Labuan Bajo-Flores \\
\hline 12 & KLM AMALIA & Captain, Engineer & 5 & Komodo-Labuan Bajo-Flores \\
\hline 13 & MV PERJUANGAN & Engineers, Crew & 6 & Komodo-Labuan Bajo-Flores \\
\hline
\end{tabular}




\begin{tabular}{lllll}
14 & SANREGO & Captain, Engineer & 6 & Komodo-Labuan Bajo-Flores \\
\hline 15 & MEGA BUANA & Captain, Engineer, Crew & 5 & Bali \\
\hline 16 & BIROSTRIS & Captain, Engineer & 6 & Komodo-Labuan Bajo-Flores \\
\hline
\end{tabular}

\section{Conclusion and Recommendations}

\subsection{Conclusion}

If we could look back to around 4000 years ago when the depth of the Flores Sea had fallen to its current levels, we might view a string of tiny coral islets and what later became known now as the Sabalana Archipelago emerge from below the waves (Kench and Mann 2017). Over time, the atoll and the waters northward along the coasts of the Philippines and westward through the Solomon Islands became inhabited by an abundance of sea life, with more species than anywhere in all of the oceans of the world. In the meantime, as each islet emerged and monsoonal rains fell upon them, fresh-water aquifers, called "lenses," provided water to plants and trees whose seeds blew with the winds across the sea or floated in with the tides. In more recent times, sailors, crossing the Flores sea in their dugouts and wooden ships, took refuge on these islets where they could fish in its lagoon and find fresh water to drink.

Then, in the late $19^{\text {th }}$ century, the first settlers arrived on Balobaloang and other islets, planting bananas, manioc, breadfruit, and coconut palms, building homes and boats with timbers brought from the high islands surrounding the Flores Sea. Those first settlers found sustenance in the fishery and their coconut groves, drying fish and copra to sell or trade in port for other necessities. Thus, men from several of the islands began to sail further from home to distant ports and increasingly engage in interisland trade, sailing and returning with the monsoons with money and a wide variety of manufactured goods, some to sell to neighbors, others to make life easier for their own families (Ammarell, 1999). Meanwhile, the atoll and the life surrounding it continued to evolve, with the appearance and disappearance of new species of life while the wind, waves and currents gradually eroded and reshaped the islets sands, seemingly moving the islets over the decades. As the islets became more populated and small commercial fishing operations started to appear, greater pressures were placed first upon the fishery and, later, upon the fresh-water lenses.

Responding to regional and global markets and new technologies, the inhabitants have continually reinvented their means of livelihood, at first installing engines in and increasing the sizes of their trading ships, and soon abandoning the dugout, powered by sail and paddle, for diesel-powered planked boats, with both traders and fishers seeking their fortunes further and further from home. And when, the early $21^{\text {st }}$ century, environmental and economic pressures 
made it harder and harder to provide for their families, more highly educated villagers sought new livelihoods, some returning to the village to serve as teachers and health workers, some moving to the mainland to find work, while many younger men took their maritime knowledge and expertise, and, with the support of their elders, returned to school to gain certification to join the rapidly growing tourist industry along the coasts of Nusa Tenggara and Papua in eastern Indonesia, working for a wage under contract and returning home for one month each year during the slowest weeks of the tourist season.

Meanwhile, continuing to promote the development of tourism across Indonesia, and in addition to heavily touristed Bali, the Indonesian government has given four coastal sites in eastern Indonesia priority for the development of tourism. Three of these areas - Raja Empat in Papua, Wakatobi in Southeast Sulawesi, and Labuan Bajo in East Nusa Tenggara - have already developed diving businesses aboard tall ships, employing seamen from Balobaloang. Most recently, in 2017, the government designated Mandalika, east of Bali and on the southern coast of the island of Lombok, West Nusa Tenggara, as a special economic zone to be developed as a high-end sea-side resort area and including a seaport for tourist ships (Mandalika (resort area) 2019). This increasing focus on attracting tourists promises to have an impact on the livelihoods of Balobaloang residents. Some young children who, in the past, may have paid less attention to education, are now encouraged by their parents to be able to go to school at least up to junior high or senior high school level. After that, they may take a short course to gain the skills and certification required to work aboard tourist ships. Even for many who later leave these positions and for others who never come to work aboard tourist ships at all, education will be more widely seen as a pathway to better job opportunities and higher incomes in many other fields. Thus, this new form of livelihood, we predict, will have a particularly significant impact on the social paradigm of Balobaloang Island community as it emerges over the next decade.

But this is not the end of the story of Balobaloang and their continual reinvention of their livelihoods. With the Covid-19 virus shutting down Indonesia's tourist industry, how will these men respond? How will each of them continue to support their families? Will they return to tourism when the health crisis is over? Will the islanders be able to continue to find sustenance and incomes for the atoll's fishery? Will they be able to provide themselves with the fresh water they need? And, finally, will the tiny islets and nearby coasts eventually disappear once again beneath the waves as a result of climate change, and, if so, how will the villagers respond?

\subsection{Recommendations}

Economic development, of course, can only be carried out with sound governance, involving active and balanced participation and accountability among all of the stakeholders: various 
levels of government, the private sector, the community and the non-human environment. It must be kept especially in mind that in the development of marine tourism, sustainable development plays a critical role. On the other hand, the community will benefit directly from the tourist industry through the opening up of employment opportunities which, in turn, will increase the income of the community and the government (Chamdani, 2018). The development of sustainable marine tourism must be able to meet the needs of tourists as well as migrant workers and local residents of the destination islands while maintaining and increasing opportunities to meet future needs.

Interviews we conducted among members of the Balobaloang community indicated both continuing interest in participating in the tourist industry in eastern Indonesia and developing a tourist industry at home. In order to realize this goal, it is essential that policies and strategies be developed to continue to increase the potential of the youth of the island as the main support in the development of marine tourism plans on Balobaloang Island. For example, it was proposed that a plan be developed to restore a portion of the damaged reef to rebuild the fishery which, in turn, would attract tourists interested in SCUBA diving and spearfishing as well as living and sailing aboard local ships. Reef restoration projects funded by international foundations have already proven successful in the Spermonde Islands, Pangkep Regency, and community environmental restoration projects of various kinds have been supported through Service Learning at Hasanuddin University and elsewhere.

In addition, interviews were conducted with several government offices in Pangkep Regency. The first was conducted with the staff in the Tourism Office of Pangkep Regency. Their recommendation was that the type of tourism that has the greatest chance of success on Balobaloang Island is so-called "special interest tourism," much like that envisioned by those residents of Balobaloang whom we interviewed. The potential of tourism in other islands can provide supporting capacity in the development of tourism in the Liukang Tangaya District in the future. The potential of the youth of Balobaloang Island is seen as a valuable asset through their involvement in the Indonesian Tourism Activists Group (Kompepar). Of course, the potential of youth in Balobaloang Island can be a driver of marine tourism in the Liukang Tangaya area through the promotion and involvement of youth as perpetrators of nautical tourism in the area.

Currently, the government has succeeded in initiating the development of marine tourism in the Spermonde Archipelago, Pangkep (Liukang Tupabbiring and North Tupabbiring) with the thematic concept of the "Islands of a Thousand Wisdoms." Approximately 43 islands in the Spermonde Island group are included in the Pangkep Regency. Of the 43 islands, both inhabited and uninhabited, there are ten islands that have been declared by the Pangkep Regional 
Government to become a marine tourism destination. The ten islands are Camba-Cambang Island, Salemo, Sabutung, Saugi, Samatellu, Pedda, Clove, Badi, Banawang, and Kapoposang (Arman: 2018). Furthermore, it has been proposed by the Pangkep Regency that in 2020, studies will begin focusing on developing marine tourism on the islands of Liukang Tangaya. This group consists of 57 islands with 31 inhabited and 26 uninhabited and includes the island of Balobaloang. In addition, the Kalukuang Island Group (Liukang Kalmas) with as many as 14 islands will be focused upon. The local government is working to establish cooperation with the provincial governments of Nusa Tenggara Barat and Nusa Tenggara Timor over accessibility such that tourists could more easily move between Lombok or Labuan Bajo and Pangkep Regency. One point that already emerged that would better enable the movement of tourists is improved transportation access to the area by way of Pangkep Regency and Makassar City.

We also carried out an interview with the Department of Youth and Sports, Pangkep Regency. This interview focused on potential of young people from Balobaloang Island, many of whom already work in the tourist industry in Labuan Bajo, Raja Ampat, and Bali and how they can be involved through the Pioneering Youth concept as stipulated in Law No.40 of 2009, Article 3 on Youth. The idea behind this law is that young people who have a "pioneering spirit" need to be encouraged by mapping the interests and potential of youth with the 3P approach, namely Awareness, Empowerment, and Development. With data on youth interests and potential, it needs to be synergized with the natural resources where the youth are located by making natural resources the entrepreneurial product.

According to the staff member interviewed, there are three factors to be developed and offered to young people, namely tourism, culture, and ekraf "creative economy," or "people's use of their creative imagination to increase an idea's value" (Creative Economy, n.d.). These three sectors are easily synergized in one product, wherein tourism and culture are the attractions and creative imagination stands to add economic value. While every village or Island in Pangkep Regency has different potential and different characters, there are a number of areas that have been successfully developed through the concept of 3P for youth potential. However, they have persisted only on the islands nearest to the coastal cities, especially in the Liukang Tupabbiring District. Constraints faced by the government at the moment are: 1) Dispora (Youth Agency) Pangkep has been in operation for only four years so that there is no policy that related to youth, so the activities undertaken to date are still limited, and 2) limited access: the islands that have youth potential in tourism development and creative economy are very far from the mainland and the budget is inadequate. 
Based upon these interviews, the authors present three conclusions: 1) Young people on Balobaloang Island could be involved through the formation of a Tourism Activation Group (Kompepar) which works directly with the Pangkep Regency Tourism Office to develop marine tourism, especially special interest tourism; 2) Youth potential can be developed through the 3P Awareness, Empowerment, and Development activities through the Pangkep Regency Youth and Sports Agency. That is, Awareness includes the socialization of youth involved in the Tourism Ship Industry in Labuan Bajo, Raja Ampat, and Bali; Empowerment supports young people who have talent in diving and as tourist guides who wish to be trained would join training programs and given diving skills certificates; and Development of youth who are not directly involved in the tourist ship industry can join creative economic entrepreneurship programs such as the manufacture of miniature ships or lopi lopi as souvenirs of Balobaloang Island; and 3) Involvement of youth through the promotion of social media such as Instagram and Facebook regarding the tourism potential on Balobaloang and across the region.

\section{Appendix: Changes in Coral Reef Ecosystems}

In addition to changes that occur on land and the socio-economic aspects of the island community, this study also attempts to deepen understanding of the coral reef ecosystems that have experienced damage from blast and cyanide fishing, resulting in loss of fish and other marine species. Research on the existing conditions of coral reefs was carried out through a series of dives around the main island of Greater Balobaloang. Observations were made of the coral reef ecosystem to survey the damage due to the bombing and cyaniding since the last such survey carried out in 2005. In addition, observations were made to learn the impact of activities of the local inhabitants as well as other natural causes which have had an impact on coral damage. Observations were made on four sides of the island, each 50 meters long at different depths. Survey areas were chosen as those with the most bombing spots and sources of coral reefs and fish. The data from the dives can be seen in the following table for the four sides of the island. 


\begin{tabular}{|c|c|c|c|}
\hline Object Observation & Method & Tool Analysis & Data Output \\
\hline Coral reefs Condition & $\begin{array}{l}\text { UPT (Underwater } \\
\text { Photo Transect) }\end{array}$ & $\begin{array}{l}\text { CpCe (Coral Point with } \\
\text { Excel Extensions) }\end{array}$ & $\begin{array}{ll}\text { - } & \text { Life coral } \\
- & \text { Death coral } \\
- & \text { Biotic }\end{array}$ \\
\hline
\end{tabular}

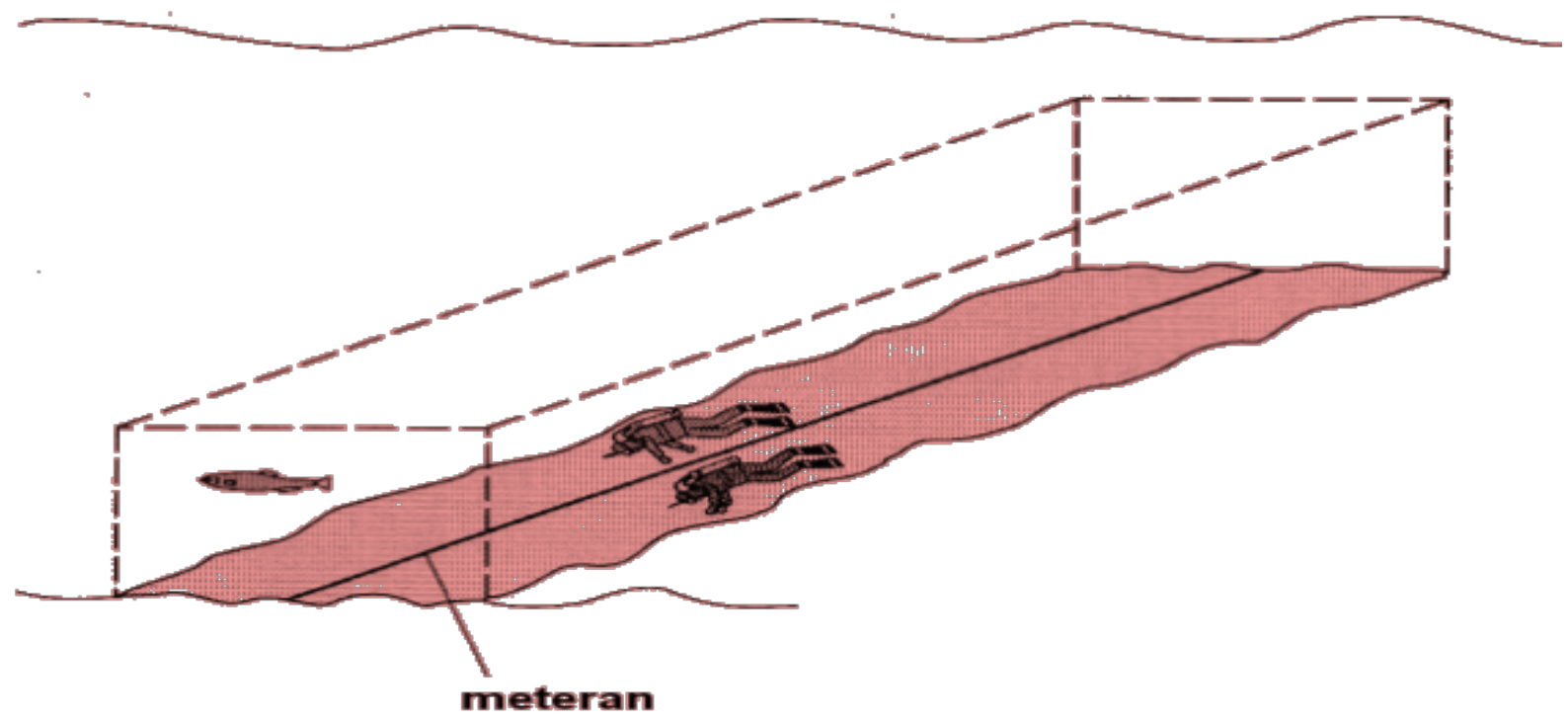

Line transect 50 m length

Figure. Survey Method for coral reefs station observation in north, west, south and east around Balobaloang Island 


\section{Stasiun 1. West}

\section{Covered Bottom water Percentage ST 1- West}

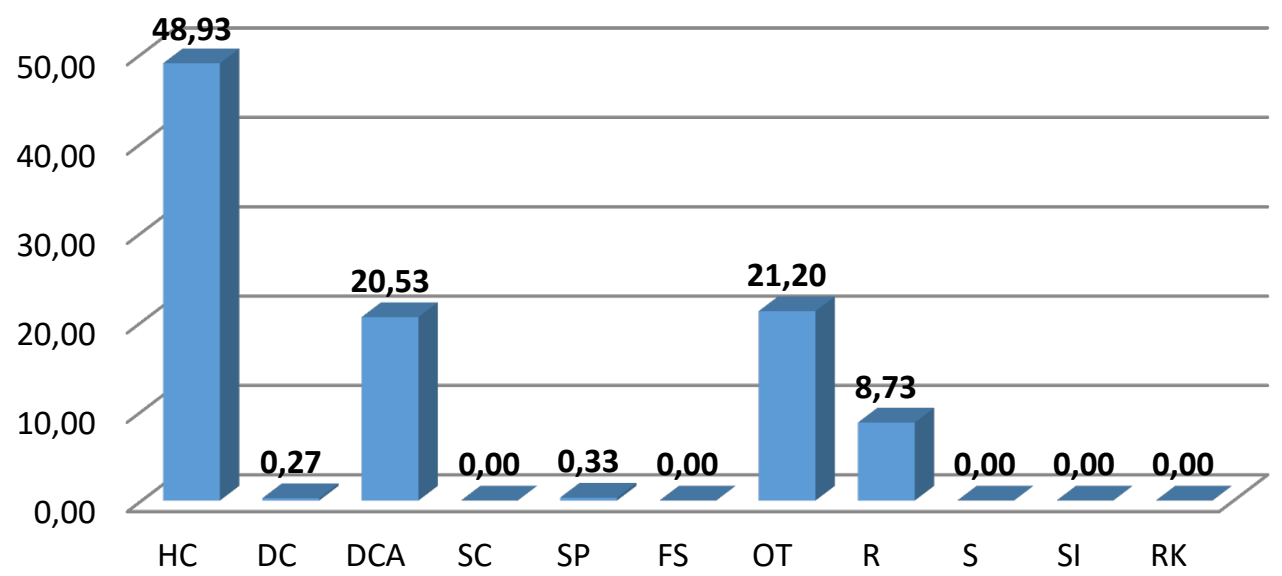

Stasiun 2. North

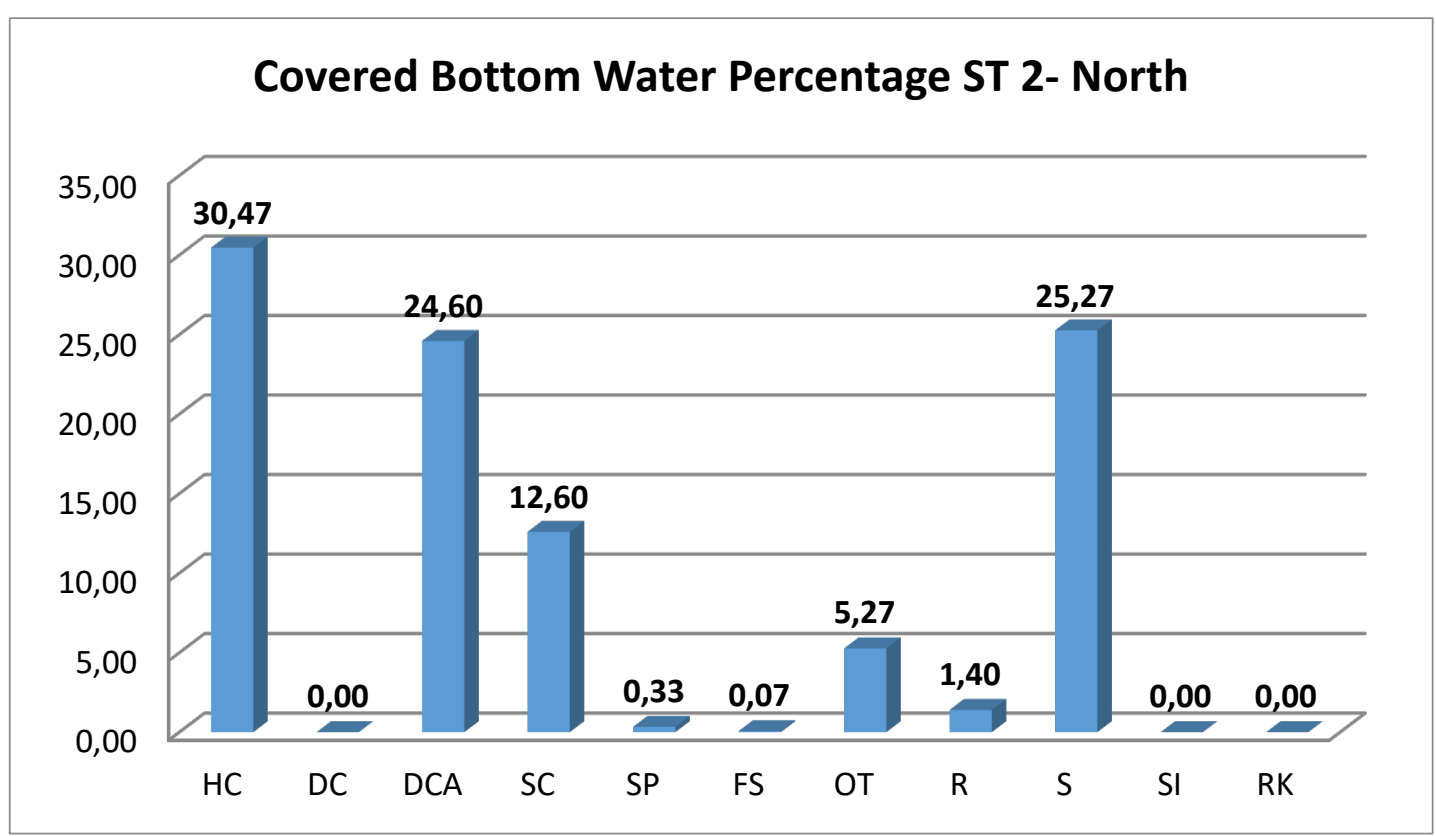




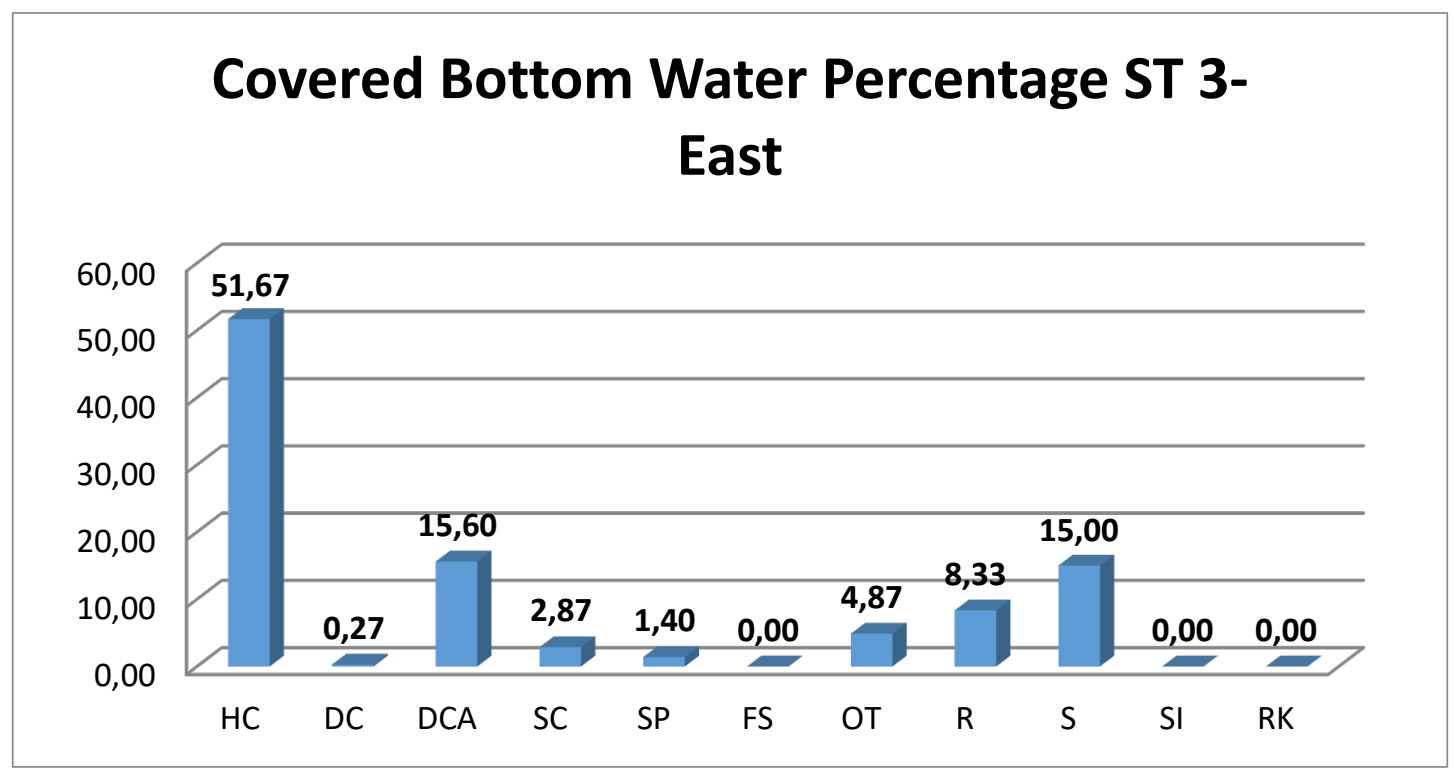

Stasiun 4. Selatan

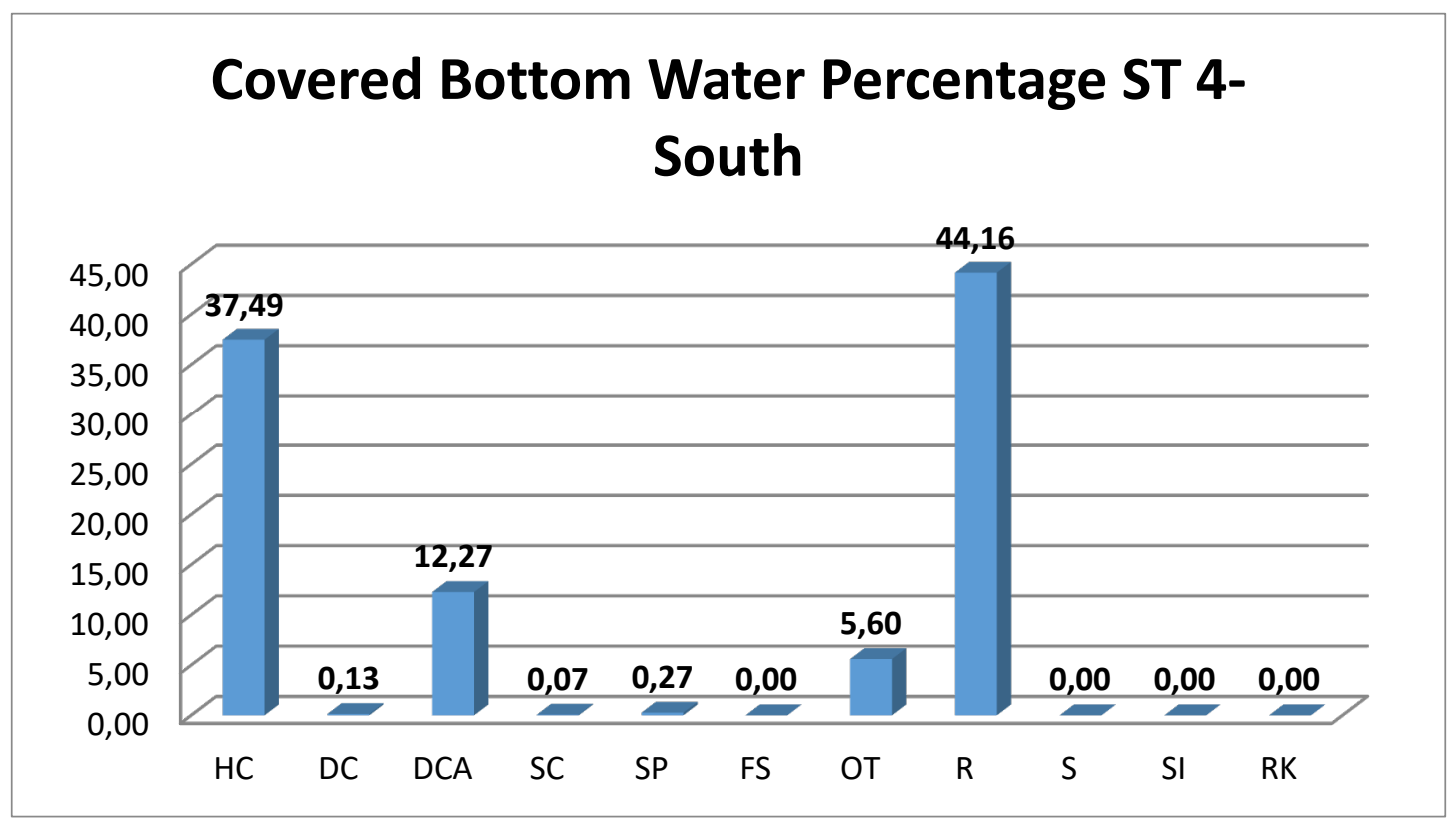


Comparison of coral reefs among 2005-2019

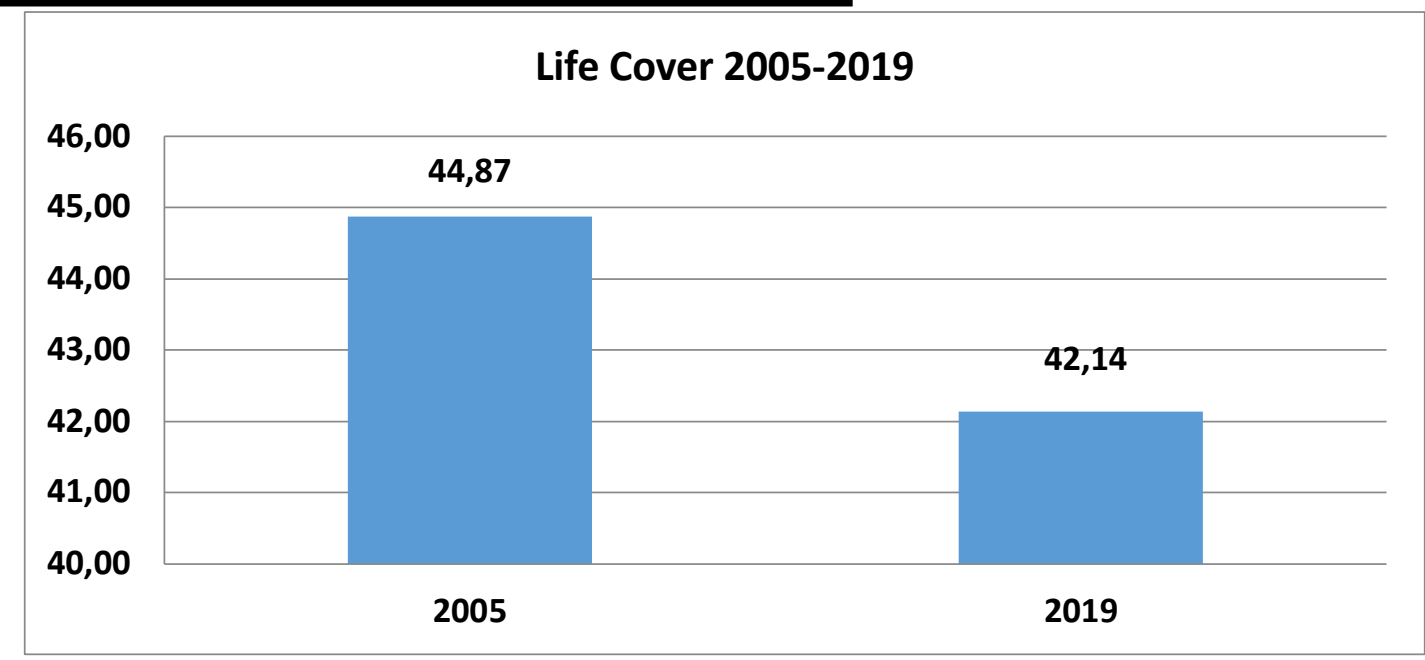

Figure. Coral reefs Comparison live cover in Balobaloang Island

Comparing the survey results, indeed there has been a less significant decline in coral cover over the past 15 years, but bombs and cyanide have been the main cause of the damage to the corals so fish have not been able to return or breed around the island which is overgrown with coral reefs. Those that have not be rehabilitated or repaired reduce the carrying capacity of fish around the island. That way the income source of fishers also decreases.

\section{Acknowledgements}

This research was supported by the Graduate School of Hasanuddin University, Makassar, in close collaboration with its Dean, Dr. Jamaluddin Jompa and Dr. M. Iqbal Djawad, Director of International Partnerships, Hasanuddin University, while Gene Ammarell served as Adjunct Professor of Anthropology. Field work on Balobaloang was made possible by the warm hospitality of the late Haji Abdul Razak and his family. The authors wish to express their deep appreciation to the faculty and staff of Hasanuddin University as well as to the residents of Balobaloang Island who graciously provided us with their assistance and co-operation. Dr. Ammarell would also like to express his thanks to Dr. M. Saleh S. Ali and his family for their hospitality and enduring friendship in Makassar. 


\section{References}

Alland Jr., A. 1975. Adaptation. Annual Review of Anthropology. 1975, Vol. 4, p59-73. Ammarell, G., 2016. Navigasi Bugis $2^{\text {nd }}$ ed. Translated by Sirimorok, N. Translation of Bugis Navigation (1999), Penerbit Inninawa, Makassar.

Ammarell, G., 1999. Bugis Navigation. Yale University Southeast Asia Studies Monograph Series, New Haven.

Ammarell, G., 2011. Just Below the Surface: Environmental Destruction and Loss of Livelihood on an Indonesian Atoll. In Everyday Life in Southeast Asia, Eds., Adams, K.M. and Gillogly, K. Indiana University Press, Bloomington, pp: 304316.

Ammarell, G., 2014. Shared Space, Conflicting Perceptions, and the Degradation of an Indonesian Fishery. In Spatial Representation and Orientation in Oceania and Indonesia, Eds. Feinberg, R. and Mawyer, A. Special issue of Ethos "Senses of Space: Multiple Models of Spatial Cognition in Oceania and Indonesia" 42(3):352375.

Arman, A., 2018. The Spermode Islands of Pangkajene dan Kepulauan: The Islands of A Thousand Wisdom. Nala Publishing House, Indonesia.

Alexa Private Cruises webpage, Retrieved June 30, 2020. Retrieved June 30, 2020, from https://alexaprivatecruises.com/indonesian-luxury-sailing-yacht/.

Barlett, P. F., 1980. Adaptive Strategies in Peasant Agricultural Production. Annual Review of Anthropology, 9(1):545-573.

Barnett, R.V. and Brennan, M.A., 2006. Integrating Youth into Community Development: Implications for Policy Planning and Program Evaluation. Journal of Youth Devevelopment, 15-19.

Bennett, J.W., 2017. The Ecological Transition: Cultural Anthropology and Human Adaptation. Routledge, New York.

Chamdani, U., 2018. Pengembangan Wisata Bahari Berkelanjutan. Deepublish, Yogyakarta.

Chozin, M., 2008. Illegal But Common: Life of Blast Fishermen in the Spermonde Archipelago, South Sulawesi, Indonesia. Unpublished Thesis, Ohio University.

Creative Economy (n.d.) In Wikipedia. Retreived June 30, 2020, from https://en.wikipedia.org/wiki/Creative_economy_(economic system). 
Dahuri, R., Rais, J., Ginting, S.P., and Sitepu, M.J., 1996. Pengelolaan Sumber Daya Wilayah Pesisir dan Lautan Secara Terpadu. Pradnya Paramita, Jakarta.

Dolezal, C. 2013. Community-based tourism in Bali: On the road towards empowerment? An interview with Djinaldi Gosana. Austrian Journal of SouthEast Asian Studies, 6(2), 366 -373.

Firdaus, A.M., Pelupessy, J.MS., and Tampubolon, J.RP. 2016. Strategi Penyelesaian Masalah Sosial Ekonomi Masyarakat Pesisir Di Kepulauan Banda Neira, Kabupaten Maluku Tengah. Jurnal Sosial Ekonomi Kelautan dan Perikanan. 11(1):55-74.

Giyanto. 2017. Evaluation Of COREMAP Phase 2 In The Eastern Indonesia Based On The Changes In Coral Coverage. Marine Research in Indonesia. 42(1): 47-55

Hapsari, A. and Ammarell, G. 2008. Sharing Paradise. Film. Documentary Educational Resources, Watertown, MA.

Helmi, A and Satria, A. 2012. Strategi Adaptasi Nelayan Terhadap Perubahan Ekologis (Fisher's Adaptation Strategies to Ecological Changes), Makara, Sosial Humaniora (Journal of Social Humaniora). 16(1): 68-78.

Hlavacs, L.A. 2006. Mapping the Effects of Blast and Chemical Fishing in the Sabalana Archipelago, South Sulawesi. Unpublished Thesis, Ohio University.

Kench, PS and Mann, T. 2017. Reef Island Evolution and Dynamics: Insights from the Indian and Pacific Oceans and Perspectives for the Spermonde Archipelago. Frontiers in Marine Science 4:145. doi: 10.3389/fmars.2017.00145

Kusnadi. 2009. Keberdayaan Nelayan dan Dinamika Ekonomi Pesisir (Fisher Empowerment and the Dynamics of the Coastal Economy). Lembaga Penelitian Universitas Jember dan Ar-Ruzz Media, Yogjakarta.

Mandalika (resort area). 2019. https://en.wikipedia.org/wiki/Mandalika_(resort_area)

Picard, D. 2007. Friction in a Tourism Contact Zone Ethnographic Field Notes From A Malagasy Village. Suomen Antropologi: Journal of the Finnish Anthropological Society 32(2).

Satria, A., Anggraini, E., and Solihin, A. 2009. Globalisasi Perikanan: Reposisi Indonesia? (Globalization of Fisheries: Repositioning Indonesia?). IPB Press, Bogor.

Steyn, A.R. 2005. Evaluating Reef Condition and the Impact of Blast-Fishing in the Coral Reefs Surrounding the Island Balobaloang, South Sulawesi, Indonesia. Unpublished Thesis, Ohio University. 
Tobing, Ph.L. 1961. Hukum Pelayaran Amanna Gappa (Maritime Law of Amanna Gappa.). Ujung Pandang: Yayasan Kebudayaan, Sulawesi Selatan dan Tenggara. Trupp, A. and Dolezal, C. 2013. Editorial: Mobilities in South-East Asia. Austrian Journal of South-East Asian Studies, 6(2), 235-2 